\title{
Schizophyllum commune induced oxidative stress and immunosuppressive activity in Spodoptera litura
}

\author{
Mandeep Kaur ${ }^{1}$, Pooja Chadha ${ }^{*}$, Sanehdeep Kaur ${ }^{1}$, Amarjeet Kaur² and Rajvir Kaur ${ }^{2}$
}

\begin{abstract}
Background: In the last few decades, considerable attention has been paid to fungal endophytes as biocontrol agents, however little is known about their mode of action. This study aimed to investigate the toxic effects of an endophytic fungus Schizophyllum commune by analyzing activities of antioxidant and detoxifying enzymes as well as morphology of haemocytes using Spodoptera litura as a model.

Results: Ethyl acetate extract of $S$. commune was fed to the larvae of $S$. litura using the artificial diet having $276.54 \mathrm{\mu g} / \mathrm{ml}$ ( $\left(\mathrm{C}_{50}\right.$ of fungus) concentration for different time durations. Exposed groups revealed significant ( $p \leq$ 0.05 ) increase in the activities of various enzymes viz. Catalase, Ascorbate peroxidase, Superoxide dismutase, Glutathione-S-Transferase. Furthermore, haemocytes showed various deformities like breakage in the cell membrane, cytoplasmic leakage and appearance of strumae in the treated larvae. A drastic reduction in the percentage of normal haemocytes was recorded in the treated groups with respect to control.

Conclusion: The study provides important information regarding the oxidative stress causing and immunosuppressant potential of S. commune against $\mathrm{S}$. litura and its considerable potential for incorporation in pest management programs.
\end{abstract}

Keywords: Basidiomycetes fungi, Polyphagous insects-pest, Antioxidant enzymes, Haemocytes

\section{Background}

Endophytes are ubiquitous in nature, forming associations with a diverse group of plant species without showing visible symptoms [1,2]. Through a symbiotic relationship with their host plant, they enhance the plant's tolerance to biotic and abiotic stresses. Various studies revealed that plants infected with endophytic fungi showed resistance to herbivory [3-5]. Several fungal species viz. Cladosporium herbarum, Rhodotorula rubra, Alternaria alternata, Epicoccum nigrum, Penicillium sp., Fusarium graminearum, Cryptococcus spp., have been reported to protect plants from herbivores [6, 7]. Some fungal endophytes act

\footnotetext{
* Correspondence: poojachadha77@yahoo.co.in

'Department of Zoology, Guru Nanak Dev University, Amritsar, Punjab, India Full list of author information is available at the end of the article
}

as insect pathogenic agents and have been reported to infect different insect species including lepidopterous larvae, aphids, thrips and many other cosmopolitan insects, which have a great concern in agriculture worldwide. They infect specific hosts, attributing little or no threat to non-target organisms or beneficial insects [8]. The antiinsect properties of endophytes have been documented by various researchers [9-11].

Many insect pathogenic fungi such as Beauveria bassiana, Clonostachys rosea, Isaria farinosa, Fusarium oxysporum, Hypocrea lixii, Gibberella moniliformis, and Trichoderma asperellum have been isolated as naturally occurring endophytes from asymptomatic plant tissues [12-17]. The insecticidal activity of fungi can be attributed to different secondary metabolites produced by them. Mycotoxins viz. aflatoxins, fumonisins, 
ochratoxins, zearalenone, have great importance in agriculture for pest management [18]. Various fungal secondary metabolites like avermectins, pantherine, destruxins, ibotenic acid, and tricholomic acid were found to be highly active against insects [19].

Although a lot of research has been done on the role of fungal endophytes as insect pathogenic agents but many of them failed to address the mode of action [20-22]. In order to discover the insecticidal potential, the effect on antioxidant and detoxifying enzymes in insects should be evaluated. In healthy animals, a balance between the production and elimination of reactive oxygen species (ROS) occur but an imbalance between the production and detoxification of ROS by the biological system results in oxidative stress [23]. Insects have a complex enzymatic and non-enzymatic defense system to encounter oxidative stress. The system regulates the level of lipid peroxidation and prevents the damage to DNA, proteins and other cytotoxic effects [24]. The main antioxidant enzymes in insects are catalase (CAT), Ascorbate peroxidase (APOX) and superoxide dismutase (SOD) [24, 25]. SOD catalyzes the dismutation of superoxide radicals into oxygen and $\mathrm{H}_{2} \mathrm{O}_{2}$. CAT and APOX catalyze the dismutation of $\mathrm{H}_{2} \mathrm{O}_{2}$ into oxygen and water. Another detoxifying enzyme, glutathione-S-transferase (GST), eliminates hydroperoxides from the cells [26, 27]. Various xenobiotics incite the production of reactive oxygen species (ROS) and unbalance the antioxidant-pro-oxidant equilibrium, ultimately induce oxidative damage, cytotoxicity or immunotoxicity and an increase in insects' mortality [28-31]. Such effects arise either from the pro-oxidant activity which can be observed as lipid peroxidation or altered antioxidant enzyme activity. So, these parameters are significant while estimating the stress caused by xenobiotics.

Insect haemocytes play an active role in providing immunity. They consist of a mixture of cells having different morphological and biological functions. The haemocytes are competent in discriminating stranger agents, mediates phagocytosis, encapsulation, cytotoxicity, wound repair and coagulation $[32,33]$. So they play an important role in providing defense against parasites, pathogens and other foreign bodies entering hemocoel [34-37]. Several studies revealed the effect of biopesticides on haemocytes count but the morphological alterations in haemocytes have not yet been studied. As haemocytes play an important role in providing cellular immune defense, the negative impact on haemocytes also reflects immunosuppressant nature.

On the basis of the aforementioned discussion, the study was conducted to decipher the effect of ethyl acetate extract of Schizophyllum commune on the activity of antioxidant, detoxifying enzymes and morphology of haemocytes of Spodoptera litura, one of the major polyphagous pest.

\section{Results}

The results of the present study have shown in Fig. 1a-h and Figs 2, 3, 4 and 5.

Fig. $1 \mathrm{a}, \mathrm{b}$ reveals a significant increase (t-test, $p \leq 0.05$ ) in catalase (CAT) activity in both haemolymph and midgut tissue of treated larvae, as compared to control. The maximum hike was observed at $96 \mathrm{~h}$, where values are 3.68 and 3.87 fold higher in haemolymph (Fig. 1a) and midgut (Fig. 1b) of treated larvae as compared to control, respectively. ANOVA followed by Tukey's test revealed the significant $(\mathrm{p} \leq 0.05)$ effect of duration of exposure for both tissues.

Change in Ascorbate peroxidase (APOX) activity in both tissues due to ingestion of ethyl acetate extract of S. commune is given in Fig. 1c, d. After $24 \mathrm{~h}$ of exposure, the value of APOX increased 3.37 fold in haemolymph and 2.43 fold in midgut tissue as compared to control. Furthermore, an increase in the activity was observed with increase in the duration of exposure. The value was found to be increased by 8.01 times in haemolymph (Fig. 1c) and 5.32 times in midgut (Fig. 1d) of $96 \mathrm{~h}$ exposure time group as compared to control. Significant (Tukey's test, $p \leq 0.05$ ) effect of duration was observed in both haemolymph and midgut.

Similar effects were observed on the activities of Superoxide dismutase (SOD) (Fig. 1e, f) and Glutathione-STransferase (GST) (Fig. 1g, h). The values of SOD and GST were increased significantly (t-test, $p \leq 0.05$ ) in all exposure time groups as compared to control, in both the tissues investigated. The SOD activity was maximum at $96 \mathrm{~h}$ exposure group where 1.53 fold (haemolymph) (Fig. 1e) and 4.14 fold (midgut) (Fig. 1f) increase was observed as compared to control groups. The GST activity increased up to $72 \mathrm{~h}$ and then a slight decrease was observed in $96 \mathrm{~h}$ exposure group in both tissues (Fig. 1g, h). The effect of duration of exposure was found to be significant (Tukey's test, $p \leq 0.05$ ) for SOD activity in both tissues and for GST activity in midgut tissue. GST activity increased non-significantly in the haemolymph of treated groups.

SEM studies revealed various morphological deformities in haemocytes of $96 \mathrm{~h}$ treated larvae of S. litura. As compared to normal plasmatocytes, treated ones showed cell membrane shrinkage, breakage in the membrane and cytoplasmic leakage (Fig. 2). Similarly, granulocytes also showed strume and surface abnormalities in the treated group (Fig. 3).

Cell membrane shrinkage was also observed in prohaemocytes of treated larvae (Fig. 4). Overall the morphology of haemocytes was found to be highly disrupted after treatment with ethyl acetate extract of $S$. commune for $96 \mathrm{~h}$ which may ultimately lead to the immunosuppressive effect.

Relative to the control, the percentage of haemocytes showing various deformities were significantly increased 

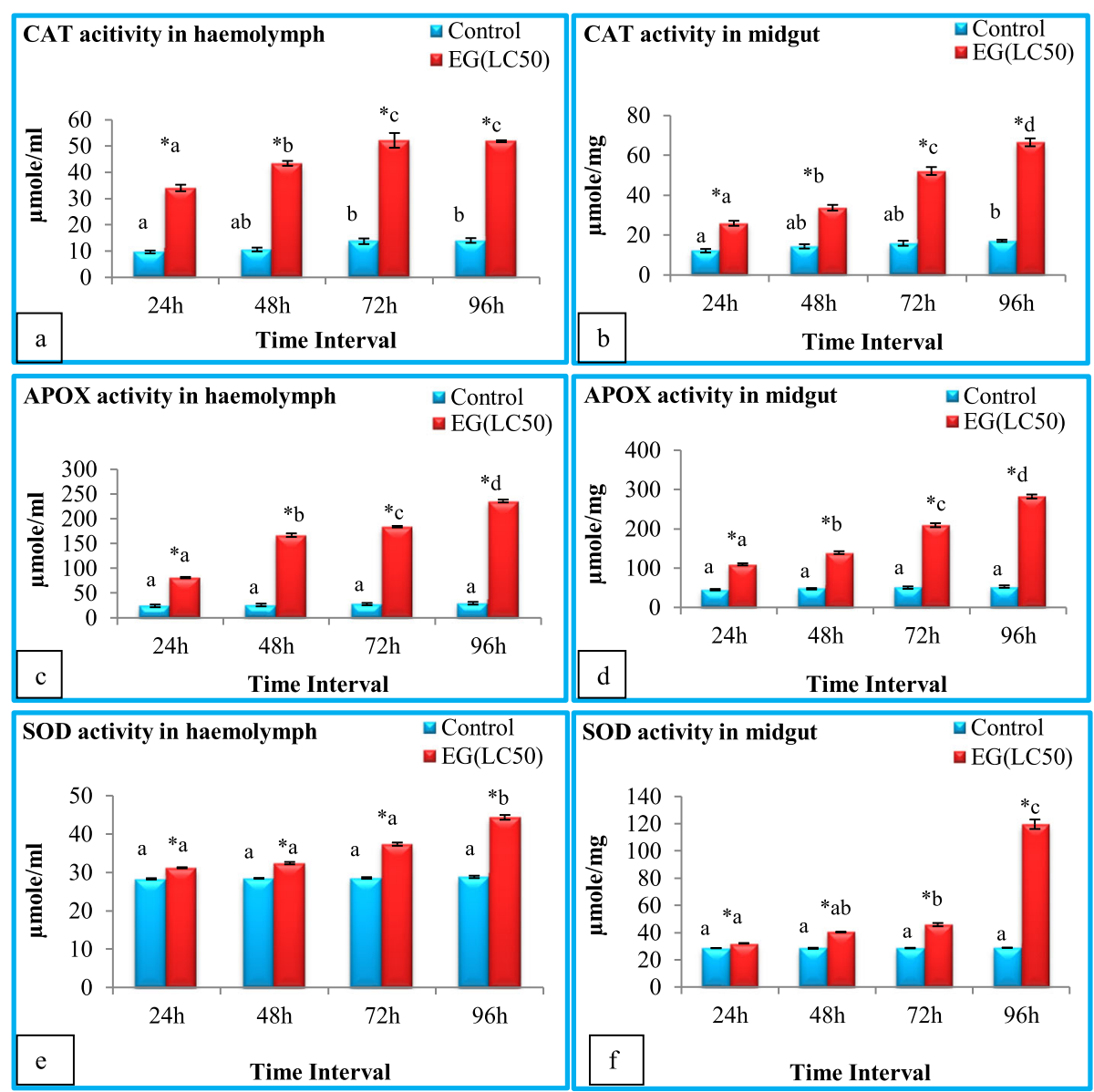

$\begin{array}{ll}\text { SOD activity in midgut } & \square \text { Control } \\ & \square \mathrm{EG}(\mathrm{LC} 50)\end{array}$
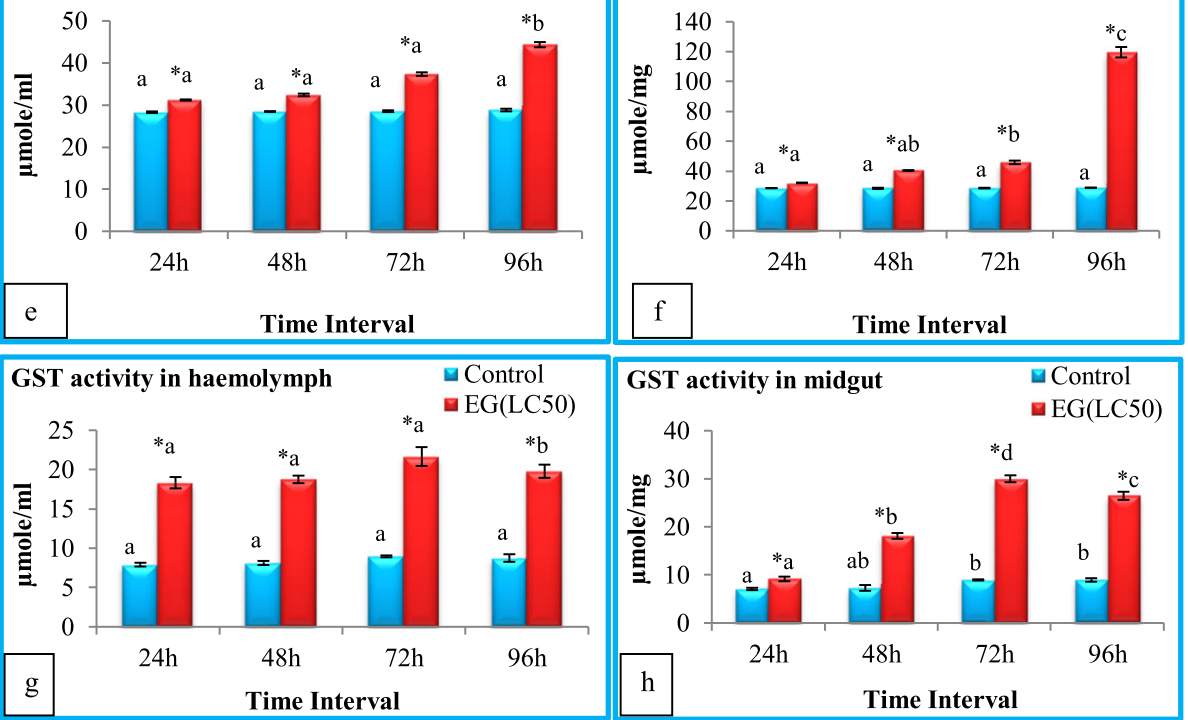

Fig. 1 a-h Catalase (CAT), Ascorbate peroxidase (APOX), Superoxide dismutase (SOD), and Glutathione-S-Transferase (GST) activity in haemolymph and midgut of $S$. litura after treatment with ethyl acetate extract of $S$. commune at different time intervals. EG = Exposed group. Bars represent mean \pm S.E. * Ascribes the significant difference between exposed group and control group (t-test, $p \leq 0.05$ ). Different letters $a, b, c, d$ are significantly different (Tukey's test, $p \leq 0.05$ ) and signify the effect of duration. The enzyme activity was expressed as $\mu$ mole/ml (haemolymph) and $\mu \mathrm{mole} / \mathrm{mg}$ (midgut) weight

in treated larvae because of the toxic effects of the fungal extract. After $96 \mathrm{~h}$ of feeding, the percentage of cells showing various deformities was $85.00 \%$ as compared to $6.66 \%$ in control (Fig. 5).

\section{Discussion}

In the last few decades, endophytic fungi have attracted considerable attention as biocontrol agents in sustainable agriculture. They are known to have several advantages as compared to synthetic pesticides [14]. To date, several studies have demonstrated the fungal endophytes as insect pathogens but many of them failed to address the mode of action [20-22].

Insects have evolved multiple defense mechanisms including antioxidant and cellular immune defense, to respond to pathogens $[24,25,32,33]$. Antioxidant defense system in insects consists of a network of protective 

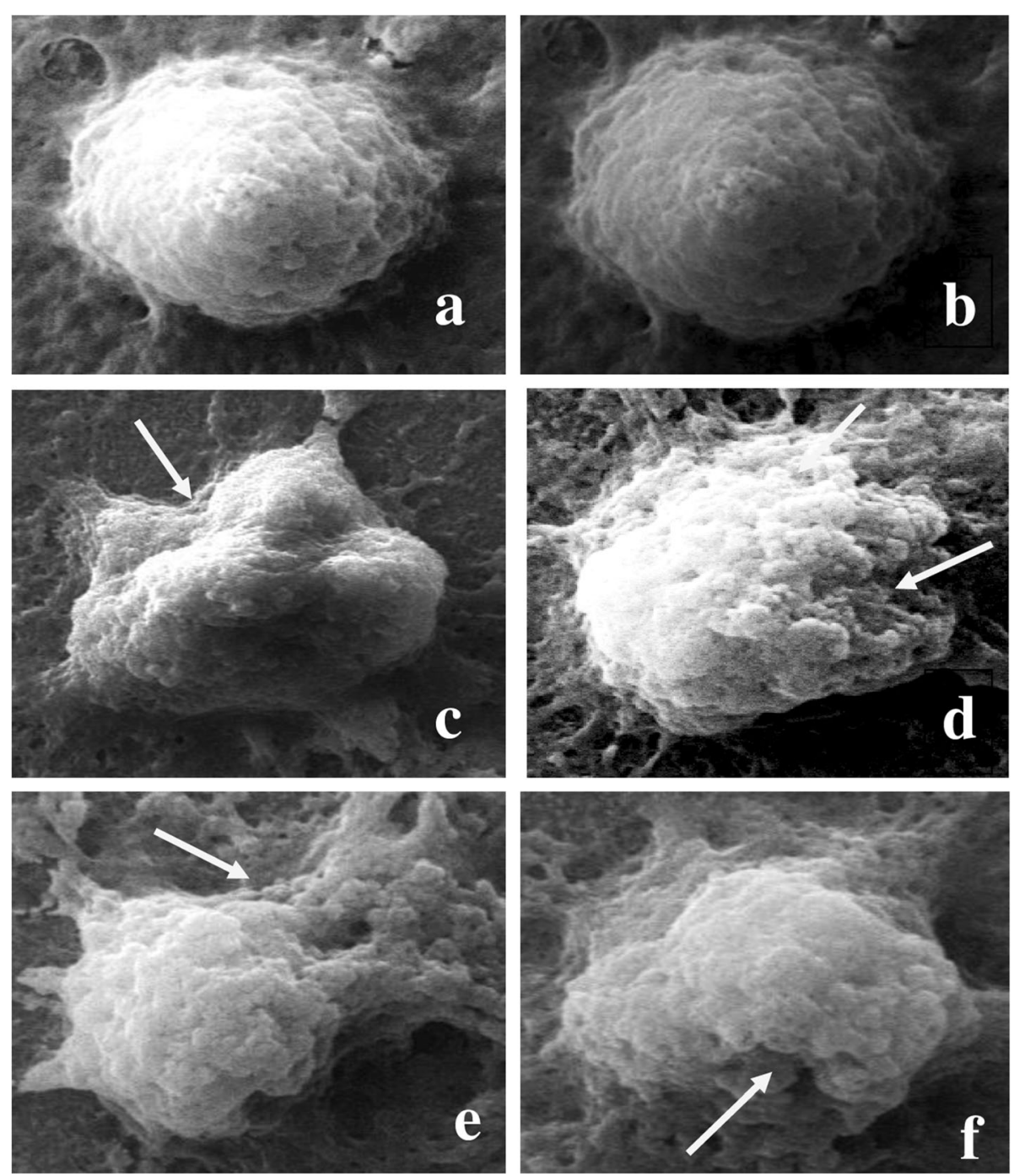

Fig. 2 Microphotographs showing haemocytes (Plasmatocytes) (a-b). Normal haemocyte; (c-f). Various deformities observed in haemocytes after treatment with ethyl acetate extract of S. commune; c. Cell membrane shrinkage of haemocyte; $\mathbf{d}$-f. Breakage in membrane and cytoplasmic leakage
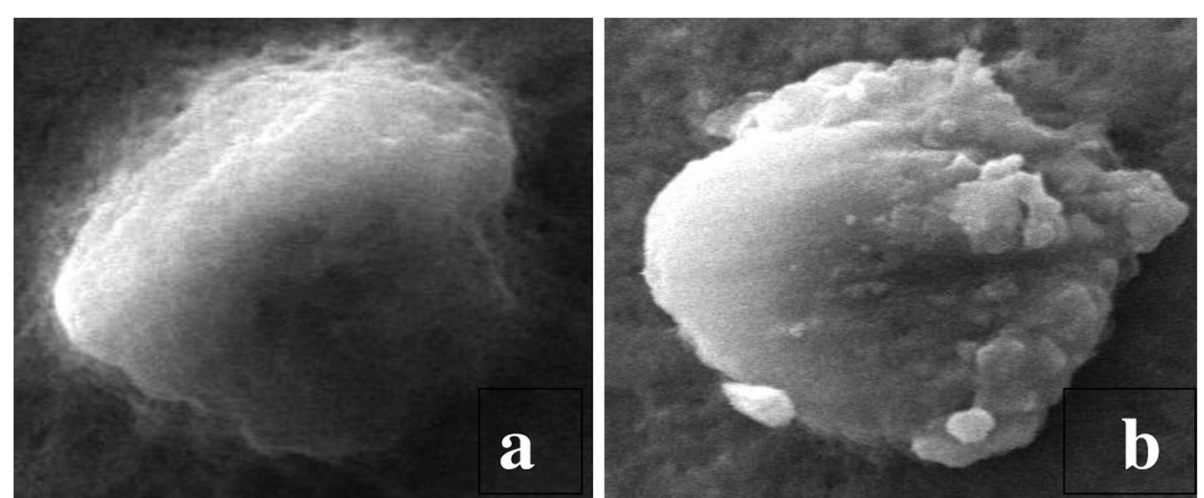

Fig. 3 Microphotographs showing haemocytes (Granulocytes) (a). Normal haemocyte; (b). Strumae and surface abnormalities in haemocytes after treatment with ethyl acetate extract of S. commune 

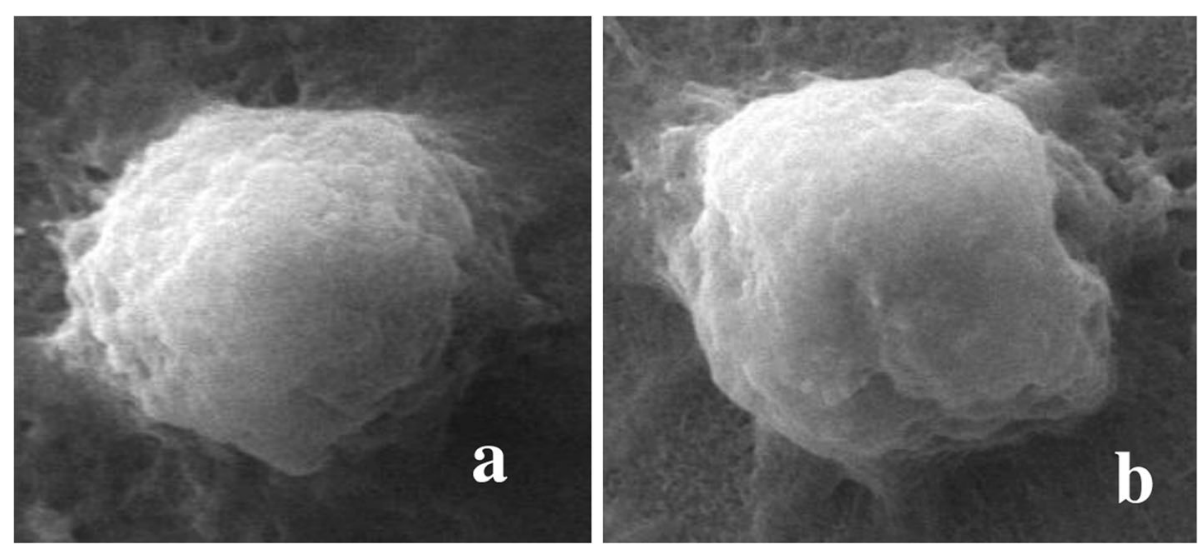

Fig. 4 Microphotographs showing haemocytes (prohaemocyte) (a). Normal haemocytes (b). Cell membrane shrinkage in haemocyte after treatment with ethyl acetate extract of $\mathrm{S}$. commune

enzymes such as Catalase (CAT), Ascorbate peroxidase (APOX), Superoxide dismutase (SOD) and GlutathioneS-Transferase (GST) which work coordinately to maintain the state of dynamic equilibrium in organisms, keeping reactive oxygen species (ROS) level low to prevent the oxidative stress induced cellular damage [24]. SOD catalyzes the dismutation of superoxide anion to hydrogen peroxide, which is subsequently detoxified to oxygen and water by catalase, ascorbate peroxidase or GST. Previous studies have demonstrated that, after fungal infection, protection systems of insects are activated to ward off infection and to maintain the normal physiological activities [38-42]. In our study, a significant increase in CAT, APOX and SOD activities were noticed in larvae of Spodoptera litura after treatment with ethyl acetate extract of Schizophyllum commune. Similarly, Karthi et al. [43] reported the increase in superoxide dismutase (SOD), catalase (CAT), peroxidases (POX) activity under the influence of entomopathogenic fungus Aspergillus flavus in S. litura. In our research, results showed that, at $96 \mathrm{~h}$, the activities of CAT, APOX and SOD have reached their maxima. This might be due to the activation of protective enzymes after stimulation by S. commune treatment to defend the body against oxidative damage. The three enzymes work synergistically, keeping the ROS level low and prohibiting oxidative damage. The overall activity trends were consistent with previous research $[38,44-51]$.

GST as a detoxifying enzyme effectively metabolizes the exogenous toxic compounds and plays a crucial role

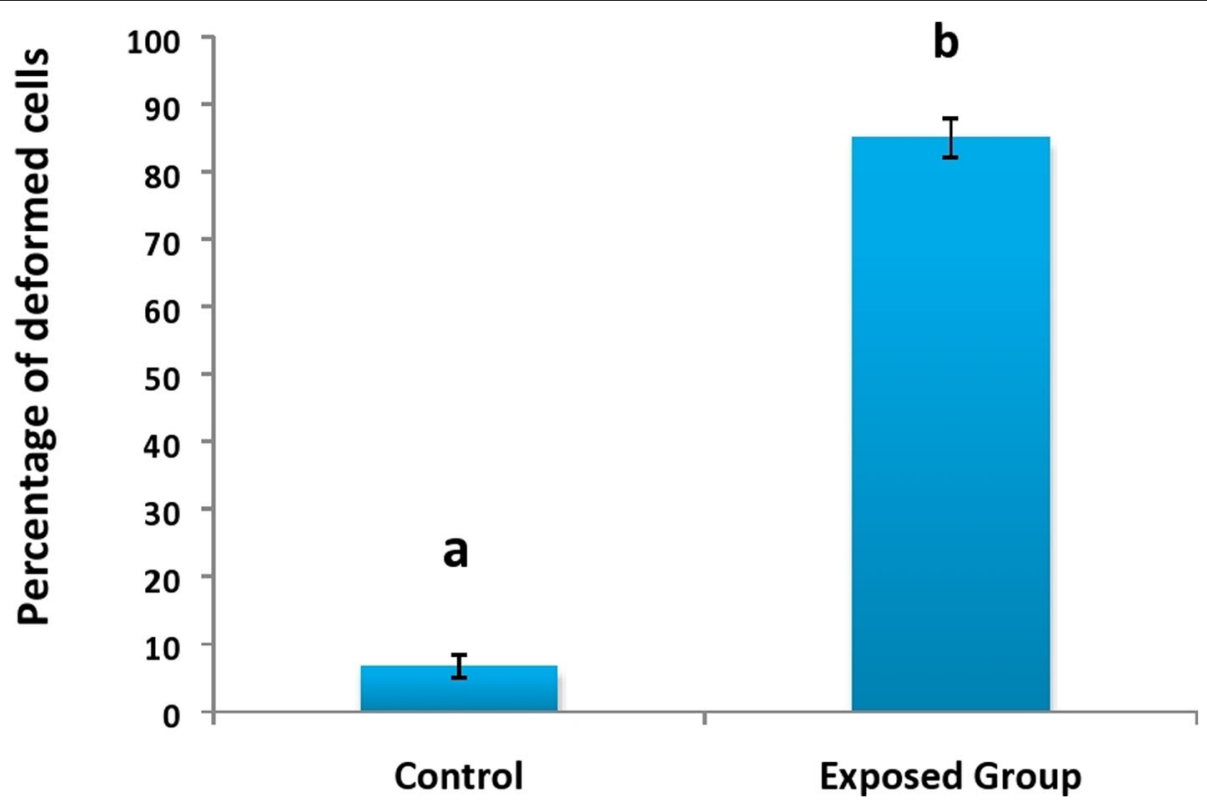

Fig. 5 The percentage of cells showing various deformities 
in providing defense as well as maintaining the normal physiological activities in the body [52-54]. The enzyme catalyzes the harmful compounds with glutathione and assists their discharge from the body in a non-enzymatic fashion [55]. In this research, an upsurge in GST activity was noticed when larvae of $S$. litura were fed with diet having ethyl acetate extract of S. commune. At $72 \mathrm{~h}$, GST activity reached its maximum level. However, at $96 \mathrm{~h}$, a slight decrease was observed. The results were according to an earlier report which indicated the elevated activity of GST in response to entomopathogenic fungus Beauveria bassiana in Andrallus spinidens (Fabricius) [56]. Ding et al. [38] and Jia et al. [57] observed a similar trend in GST activity after exposure to fungus B. bassiana and Metarhizium anisopliae in Xylotrechus rusticus (Linnaeus) and Locusta migratoria (Linnaeus), respectively.

Cellular immune defense in insects is because of different haemocytes which play a vital role in providing immunity to insects against pathogens. There are different classes of haemocytes which have been morphologically and functionally characterized in various insects [33, 58-64]. The most common types of haemocytes reported in the literature are prohemocytes, granulocytes, plasmatocytes, and oenocytoids. Their multifunctional roles are phagocytosis, encapsulation, cell agglutination, detoxification, etc. [58-61]. Change in number and configuration of haemocytes ultimately affect the immunity and health of insects $[65,66]$.

Scanning electron microscopic observations in the present study revealed various morphological deformities within haemocytes of S. litura larvae, exposed to ethyl acetate extract of $S$. commune. The percentage of normal haemocytes was found to be highly reduced in the treated groups. As compared to control, various cellular deformities observed in treated ones are cell perforations, rupturing of haemocytes with cytoplasmic leakage and irregular variation on the surface of haemocytes. Many of them showed resemblance with changes observed in haemocytes of Bombyx mori (Linnaeus) after exposure to destruxin A [67]. There are very fewer reports available in literature revealing the abnormalities of insect haemocytes using SEM. This is the first finding reporting the alterations in different types of haemocytes in S. litura under SEM. The technique has been used to observe and characterize the haemocytes of different insects in various reports $[68,69]$ and also to observe the spores accumulation in the body of the insect after fungal infection [7073]. However, similar types of morphological changes as observed in the present finding were demonstrated by other workers due to entomopathogenic fungi and insecticides under light microscopy [74-77].

\section{Conclusion}

All these results suggest that $S$. commune infects $S$. litura by directly acting on the antioxidant and cellular immune defense, resulting in oxidative stress and decreased immune function. Overall, the study provides important information about the oxidative stress causing and the immunosuppressant potential of $S$. commune against $S$. litura and its considerable potential for incorporation in pest management programs.

\section{Methods}

\section{Rearing of Spodoptera litura}

Spodoptera litura (Lepidoptera) eggs were obtained from the cauliflower fields around Amritsar (India). After hatching of eggs, larvae were fed on castor leaf. Subsequent generations of the culture were maintained in the laboratory at $25 \pm 2{ }^{\circ} \mathrm{C}$ temperature, $65 \pm 5 \%$ relative humidity and 12:12 (D: L) photoperiod [78].

\section{Fungal culture isolation, production and identification}

Endophytic fungus was isolated from leaves of Aloe vera collected from Amritsar (India). The leaves were thoroughly washed with distilled water, followed by sterilization with $70 \%$ ethanol ( $2 \mathrm{~min}$ ), $5 \%$ sodium hypochlorite solution $(5 \mathrm{~min})$ and finally rinsed with sterile distilled water. Sterilized samples were cut into small pieces, and they were placed on water agar plates having ampicillin $(200 \mathrm{mg} / \mathrm{ml})$ as an antibacterial agent and incubated at $30^{\circ} \mathrm{C}$. After the emergence of hyphae, the hyphae tips were picked and cultured on PDA (potato dextrose agar) plates. Then the culture was purified and maintained on PDA for further studies [79].

The production was carried out in $50 \mathrm{ml}$ malt extract (malt extract $=20 \mathrm{~g} / \mathrm{l}$, dextrose $=20 \mathrm{~g} / \mathrm{l}$, peptone $=1 \mathrm{~g} / \mathrm{l}$, $\mathrm{pH}=5.5)$ broth in $250 \mathrm{ml}$ Erlenmeyer flask by inoculating one plug ( $1 \mathrm{~cm}$ square) taken from the periphery of an actively growing culture. The flasks were incubated at $30^{\circ} \mathrm{C}$ and $250 \mathrm{rpm}$ for 10 days. After 10 days extraction was carried out twice using ethyl acetate at $120 \mathrm{rpm}$ and $40{ }^{\circ} \mathrm{C}$. The extracts were concentrated by using rotavapor and dissolved in $1 \mathrm{ml}$ DMSO and stored at $4{ }^{\circ} \mathrm{C}$. The fungus was identified as Schizophyllum commune on morphological (Fig S1: Morphology of S. commune showing hyphae and clamp connection, characteristics of basidiomycetes under SEM) and molecular basis as indicated in our previous study [80] by using ITS1 and ITS4 primers to amplify ITS1-5.8S- rDNA- ITS2 region. Amplified ITS region was Purified and sequenced at first base sequencing (Malaysia). The sequence similarity was matched with other available databases retrieved from NCBI using BLAST [81]. The sequence was deposited into GeneBank under accession number: MF680077.

\section{Toxicity test}

On the basis of bioassay studies, the $\mathrm{LC}_{50}$ value of ethyl acetate extract of $S$. commune was found to be $276.542 \mu \mathrm{g} / \mathrm{ml}$ [80]. This concentration is selected for, to 
analyze its effect on antioxidant and detoxification enzymes and to decipher various morphological changes in haemocytes.

\section{Antioxidant enzyme activities}

To evaluate the effect of fungal extracts on antioxidant enzymes, the third instar larvae (12 days old) were fed with fungal extracts supplemented diet having a concentration $276.54 \mu \mathrm{g} / \mathrm{ml}$. The enzyme activities [Superoxide dismutase (SOD), catalase (CAT), Ascorbate peroxidase (APOX) and Glutathione-S-Transferase (GST)] were analyzed in haemolymph and midgut of third instar (12 days) larvae.

Larvae were divided into two groups, treatment and control. The treatment group was exposed with $\mathrm{LC}_{50}$ of fungus at controlled temperature $25 \pm 2{ }^{\circ} \mathrm{C}$ and relative humidity $65 \pm 5 \%$. The second group was treated with control diet ( $0.5 \%$ DMSO) at the same conditions of temperature and relative humidity. The effect of fungal extract has been recorded after different time intervals $(24 \mathrm{~h}, 48 \mathrm{~h}, 72 \mathrm{~h}$ and $96 \mathrm{~h})$ in enzyme activities. The experiment was replicated three times. For each treatment and control, there are 10 larvae per replication were taken.

\section{Tissue collection}

Haemolymph was collected by cutting prolegs with microscissor from 10 different larvae fed with the same concentration and then it was pooled. Pooled haemolymph (10\%) was mixed with PBS (Phosphate Buffer Saline $\mathrm{pH} 7.0)$ containing $0.01 \%$ phenylthiourea and centrifuged for $20 \mathrm{~min}$ at $10000 \mathrm{~g}, 4^{\circ} \mathrm{C}$ and supernatant obtained was used for enzyme activities studies. Similarly, midgut tissue was also taken after dissection with microscissor from 10 different larvae fed with the same concentration and homogenate $(10 \% \mathrm{w} / \mathrm{v})$ was prepared by homogenizing larval midguts (100 $\mathrm{mg}$ in $1 \mathrm{ml}$ ) in PBS. Afterwards, the homogenate was centrifuge in PBS for $20 \mathrm{~min}$ at $10000 \mathrm{~g}, 4^{\circ} \mathrm{C}$ and supernatant obtained was used for enzyme activities studies.

The extraction procedure was the same for all enzymes.

\section{Catalase (CAT) activity}

Enzyme activity was estimated according to the methodology given by Aebi [82] with slight modifications. $0.1 \mathrm{ml}$ of supernatant was added into $2.9 \mathrm{ml}$ of $\mathrm{H}_{2} \mathrm{O}_{2}$ in a cuvette. The decrease in absorbance was read at $240 \mathrm{~nm}$ for $5 \mathrm{~min}$ at $1 \mathrm{~min}$ interval $\left(25^{\circ} \mathrm{C}\right)$. The enzyme activity was expressed as $\mu \mathrm{M} / \mathrm{ml}$ (haemolymph) and $\mu \mathrm{M} / \mathrm{mg}$ (midgut) weight.

\section{Ascorbate peroxidase (APOX) activity}

The enzyme activity was calculated according to the methodology introduced by Asada [83] with slight modifications. $0.1 \mathrm{ml}$ of sample, $0.6 \mathrm{ml}$ extraction buffer $(50 \mathrm{mM}$ potassium phosphate buffer $\mathrm{pH} 7.0)$ and $0.125 \mathrm{ml}$ of $0.3 \% \mathrm{H}_{2} \mathrm{O}_{2}$ were taken in a cuvette. The decrease in absorbance was recorded at $290 \mathrm{~nm}$ for 5 min at 30 s interval $\left(25^{\circ} \mathrm{C}\right)$. The enzyme activity was expressed as $\mu \mathrm{M} / \mathrm{ml}$ (haemolymph) and $\mu \mathrm{M} / \mathrm{mg}$ (midgut) weight.

\section{Superoxide dismutase (SOD) activity}

The enzyme activity was calculated according to the methodology followed by Kono [84] with slight modifications. $0.05 \mathrm{ml}$ sample, $1.5 \mathrm{ml}$ extraction buffer $(50 \mathrm{mM}$ sodium carbonate buffer $\mathrm{pH} 10.0$ ), $0.5 \mathrm{ml}$ of $96 \mu \mathrm{M}$ NBT (Nitroblue tetrazolium), $0.1 \mathrm{ml}$ TritonX-100, $0.1 \mathrm{ml}$ of $20 \mathrm{mM}$ hydroxylamine hydrochloride were taken in cuvette and increase in absorbance was recorded at 540 $\mathrm{nm}$. The enzyme activity was expressed as $\mu \mathrm{M} / \mathrm{ml}$ (haemolymph) and $\mu \mathrm{M} / \mathrm{mg}$ (midgut) weight.

\section{Glutathione- S-transferase (GST) activity}

GST activity was estimated using the method of Habig et al. [85] with minor modifications. $50 \mu \mathrm{l}$ of $10 \mathrm{mM}$ CDNB (1- chloro-2, 4-dinitrobenzene), $100 \mu \mathrm{l}$ GSH (Reduced glutathione), $50 \mu \mathrm{l}$ of sample and 0.2 $\mathrm{ml}$ of $0.1 \mathrm{M}$ sodium phosphate buffer containing PTU (phenylthiourea) were incubated at $25^{\circ} \mathrm{C}$ and absorbance change was recorded at $340 \mathrm{~nm}$ for $5 \mathrm{~min}$ at 1 min interval. The enzyme activity was expressed as $\mu \mathrm{M} / \mathrm{ml}$ (haemolymph) and $\mu \mathrm{M} / \mathrm{mg}$ (midgut) weight.

\section{Effect on the morphology of haemocytes}

To study the morphological alterations in haemocytes, the methodology of Wang et al. [86] with slight modifications was followed. The haemolymph of insects exposed for $96 \mathrm{~h}$ was bled on termanox discs after cutting prolegs of larvae. It was allowed to dry and fixed with $2.5 \%$ glutaraldehyde in $0.1 \mathrm{M}$ cacodylate buffer ( $\mathrm{pH} 7.2$ ) for $2 \mathrm{~h}$. After this, sequential dehydration was done by using a graded series of $25 \%$ ethanol followed by $50,70,90 \%$ and at the end with absolute $(100 \%)$ alcohol. Then discs were placed in a dry chamber for proper drying. At the end silver coating was done by mounting samples on aluminium stubs and haemocytes were observed under SEM at a magnification of $10.00 \mathrm{KX}$ operated at $10 \mathrm{KV}$. The percentage of cells showing various deformities were also calculated in the treatment and control group after $96 \mathrm{~h}$ exposure to $S$. commune ethyl acetate extract. 


\section{Statistical analysis}

To study the effect of duration one way analysis of variance (ANOVA) with Tukey's test was performed and to study the effect of treatment student's t-test was applied.

\section{Supplementary information}

Supplementary information accompanies this paper at https://doi.org/10. 1186/s12866-020-01831-6.

Additional file 1: Figure S1. Morphology of S. commune showing hyphae and clamp connection (characterstics of basidiomycetes) under SEM.

\section{Abbreviations}

CAT: Catalase; APOX: Ascorbate peroxidase; SOD: Superoxide dismutase; GST: Glutathione- S-Transferase

\section{Acknowledgements}

The grants received from UGC (University Grant Commission), New Delhi, India under SAP (Special Assistance Program) and UPE schemes are thankfully acknowledged.

\section{Authors' contributions}

PC, AK and SK designed the study and analyzed the content. MK performed the experiments and analyzed the content related to it. RK helped in fungus identification as well as isolation. All authors have read and approved the manuscript.

\section{Funding}

This work was supported by Grant from UGC (University Grant Commission) - SAP (Special Assistance Program) and UPE grants. Grant number of SAP- No.F.4-4/2016/DRS-I (SAP-II). Funding bodies had no roles in study design and collection, analysis, and interpretation of data, or preparation of the manuscript.

\section{Availability of data and materials}

All data generated or analyzed during this study are included in this article and its additional files.

\section{Ethics approval and consent to participate}

Not applicable.

\section{Consent for publication}

Not applicable.

\section{Competing interests}

The authors declare that they have no competing interests.

\section{Author details}

'Department of Zoology, Guru Nanak Dev University, Amritsar, Punjab, India. 2Department of Microbiology, Guru Nanak Dev University, Amritsar, Punjab, India.

Received: 8 January 2020 Accepted: 25 May 2020

Published online: 29 May 2020

\section{References}

1. Hartley SE, Gange AC. Impacts of plant symbiotic fungi on insect herbivores: mutualism in a multitrophic context. Annu Rev Entomol. 2009;54(1):323-42.

2. Saikkonen $\mathrm{K}$, Lehtonen P, Helander M, Koricheva J, Faeth SH. Model systems in ecology: dissecting the endophyte-grass literature. Trends Plant Sci. 2006; 11(9):428-33.

3. Ahmad S, Johnson-Cicalese JM, Dickson WK, Funk CR. Endophyte-enhanced resistance in perennial ryegrass to the bluegrass billbug. ol Exp Appl. 1986; 41(1):3-10.
4. Arnold AE, Mejía LC, Kyllo D, Rojas El, Maynard Z, Robbins N, Herre EA. Fungal endophytes limit pathogen damage in a tropical tree. Proc Natl Acad Sci U S A. 2003;100(26):15649-54.

5. Ambrose KV, Belanger FC. SOLiD-SAGE of endophyte-infected red fescue reveals numerous effects on host transcriptome and an abundance of highly expressed fungal secreted proteins. PLoS One. 2012;7(12):e53214.

6. Larran S, Monaco C, Alippi HE. Endophytic fungi in leaves of Lycopersicon esculentum mill. World J Microbiol Biotechnol. 2001;17(2):181-4.

7. dos Santos SB, dos Santos TT. Endophytic fungi in economically important plants: ecological aspects, diversity and potential biotechnological applications. JBFS. 2017:4(2):113-26.

8. Akutse KS, Fiaboe KK, Van den Berg J, Ekesi S, Maniania NK. Effects of endophyte colonization of Vicia faba (Fabaceae) plants on the life-history of leafminer parasitoids Phaedrotoma scabriventris (Hymenoptera: Braconidae) and Diglyphus isaea (Hymenoptera: Eulophidae). PLoS One. 2014;9(10):e109965.

9. Daisy BH, Strobel GA, Castillo U, Ezra D, Sears J, Weaver DK, Runyon JB. Naphthalene, an insect repellent, is produced by Muscodor vitigenus, a novel endophytic fungus. Microbiology. 2002;148(11):3737-41.

10. Nazir A, Rahman HA. Secrets of plants: Endophytes. Int J Plant Biol. 2018; 9(1):43-6

11. Lacava PT, Azevedo JL. Biological control of insect-pest and diseases by endophytes. Adv Endophytic Res. 2014;81(13):231-56.

12. Bills GF, Polishook JD. Microfungi from Carpinus caroliniana. Can J Bot. 1991; 69(7):1477-82

13. Cherry AJ, Lomer CJ, Djegui D, Schulthess F. Pathogen incidence and their potential as microbial control agents in IPM of maize stem borers in West Africa. Biocontrol. 1999;44(3):301-27.

14. Vega FE, Posada F, Aime MC, Pava-Ripoll M, Infante F, Rehner SA. Entomopathogenic fungal endophytes. Biol Control. 2008;46(1):72-82

15. Akello J, Sikora R. Systemic acropedal influence of endophyte seed treatment on Acyrthosiphon pisum and Aphis fabae offspring development and reproductive fitness. Biol Control. 2012:61(3):215-21.

16. Akello J. Biodiversity of fungal endophytes associated with maize, sorghum and Napier grass and the influence of biopriming on resistance to leaf mining, stem boring and sap sucking insect pests. Bonn: ZEF. 2012:86(2):1-4

17. Akutse KS, Maniania NK, Fiaboe KK, Van den Berg J, Ekesi S. Endophytic colonization of Vicia faba and Phaseolus vulgaris (Fabaceae) by fungal pathogens and their effects on the life-history parameters of Liriomyza huidobrensis (Diptera: Agromyzidae). Fungal Ecol. 2013;6(4):293-301.

18. Huffman J, Gerber R, Du L. Recent advancements in the biosynthetic mechanisms for polyketide-derived mycotoxins. Biopolymers. 2010;93(9):764-76.

19. Busi S, Rajkumari J, Hnamte S. Feeding deterrence, acute toxicity and sublethal growth effects of kojic acid isolated from Aspergillus funiculosus. Nat Prod J. 2014:4(1):18-22.

20. Sánchez-Rodríguez AR, Raya-Díaz S, Zamarreño ÁM, García-Mina JM, del Campillo MC, Quesada-Moraga E. An endophytic Beauveria bassiana strain increases spike production in bread and durum wheat plants and effectively controls cotton leafworm (Spodoptera littoralis) larvae. Biol Control. 2018 116(1):90-102

21. Powell WA, Klingeman WE, Ownley BH, Gwinn KD. Evidence of endophytic Beauveria bassiana in seed-treated tomato plants acting as a systemic entomopathogen to larval Helicoverpa zea (Lepidoptera: Noctuidae). J Entomol Sci. 2009:44(4):391-6.

22. Abraham S, Basukriadi A, Pawiroharsono S, Sjamsuridzal W. Insecticidal activity of ethyl acetate extracts from culture filtrates of mangrove fungal endophytes. Mycobiology. 2015:43:137-49.

23. Rahman I, Adcock IM. Oxidative stress and redox regulation of lung inflammation in COPD. Eur Res. 2006;28(1):219-42.

24. Felton GW, Summers CB. Antioxidant systems in insects. Arch Insect Biochem Physiol. 1995;29(2):187-97.

25. Wang Y, McAllister TA, Rode LM, Beauchemin KA, Morgavi DP, Nsereko VL, Iwaasa AD, Yang W. Effects of an exogenous enzyme preparation on microbial protein synthesis, enzyme activity and attachment to feed in the rumen simulation technique (Rusitec). Br J Nutr. 2001;85(3):325-32.

26. Ahmad S. Oxidative stress from environmental pollutants. Arch Insect Biochem Physiol. 1995;29(2):135-57.

27. Dubovskiy IM, Martemyanov W, Vorontsova YL, Rantala MJ, Gryzanova EV, Glupov W. Effect of bacterial infection on antioxidant activity and lipid peroxidation in the midgut of Galleria mellonella L. larvae (Lepidoptera, Pyralidae). Comp Biochem Physiol C Toxicol Pharmacol. 2008;148(1):1-5. 
28. Adamski ZB, Ziemnicki KA, Fila KA, Zikic R, Stajn A. Effects of long-term exposure to fenitrothion on Spodoptera exigua and Tenebrio molitor larval development and antioxidant enzyme activity. Biol Lett. 2003;40(1):43-52.

29. Freeman BA, Crapo JD. Biology of disease: free radicals and tissue injury. Lab Investig. 1982;47(5):412-26.

30. Krishnan N, Sehnal F. Compartmentalization of oxidative stress and antioxidant defense in the larval gut of Spodoptera littoralis. Arch Insect Biochem Physiol. 2006;63(1):1-10.

31. Hyrsl P, Buyukguzel E, Buyukguzel K. The effects of boric acid-induced oxidative stress on antioxidant enzymes and survivorship in Galleria mellonella. Arch Insect Biochem Physiol. 2007;66:23-31.

32. Lanot R, Zachary D, Holder F, Meister M. Postembryonic hematopoiesis in Drosophila. Dev Biol. 2001;230(2):243-57.

33. Lavine MD, Strand MR. Insect hemocytes and their role in immunity. Insect Biochem Mol Biol. 2002;32(10):1295-309.

34. Lackie AM. Haemocyte behaviour. Adv Insect Physiol. 1988;21:185-78.

35. Ratcliffe NA, Gagen SJ. Cellular defense reactions of insect hemocytes in vivo: nodule formation and development in Galleria mellonella and Pieris brassicae larvae. J Invertebr Pathol. 1976;28(3):373-82.

36. Ratcliffe NA, Rowley AF, Fitzgerald SW, Rhodes CP. Invertebrate immunity: basic concepts and recent advances. Int Rev Cytol. 1985:97:183-350.

37. Hoffmann JA. Immune response of insects. Dev Comp Immunol. 1994;18:37-8.

38. Ding JN, Zhang HH, Chi DF. Effects of a pathogenic Beauveria bassiana (Hypocreales: Cordycipitaceae) strain on detoxifying and protective enzyme activities in Xylotrechus rusticus (Coleoptera: Cerambycidae) larvae. Fla Entomol. 2015;98(4):1148-56.

39. Cui C, Wang Y, Liu J, Zhao J, Sun P, Wang S. A fungal pathogen deploys a small silencing RNA that attenuates mosquito immunity and facilitates infection. Nat Commun. 2019;10(1):1-0.

40. Canteri de Souza P, Custódio Caloni C, Wilson D, Sergio Almeida R. An invertebrate host to study fungal infections, mycotoxins and antifungal drugs: Tenebrio molitor. J Fungi. 2018;4(4):125.

41. Fiorotti J, Menna-Barreto RF, Gôlo PS, Coutinho-Rodrigues CJ, Bitencourt RO, Spadacci-Morena DD, da Costa Al, Bittencourt VR. Ultrastructural and cytotoxic effects of Metarhizium robertsii infection on Rhipicephalus microplus hemocytes. Front Physiol. 2019;10:1-9.

42. Zhang J, Huang W, Yuan C, Lu Y, Yang B, Wang CY, Zhang P, Dobens L, Zou Z, Wang C, Ling E. Prophenoloxidase-mediated ex vivo immunity to delay fungal infection after insect ecdysis. Front Immunol. 2017:8:1445-52.

43. Karthi S, Vaideki K, Shivakumar MS, Ponsankar A, Thanigaivel A, Chellappandian M, Senthil-Nathan S. Effect of Aspergillus flavus on the mortality and activity of antioxidant enzymes of Spodoptera litura fab. (Lepidoptera: Noctuidae) larvae. Pestic Biochem Physiol. 2018:149:54-60.

44. Mutyala NB, Vadlamani P. Induced oxidative stress by Metarhizium anisopliae spp. instigates changes in lipid peroxidation and ultra structure in Periplaneta Americana. Afr. J Microbiol Res. 2013;7(38):4629-37.

45. Konstantopoulou MA, Milonas P, Mazomenos BE. Partial purification and insecticidal activity of toxic metabolites secreted by a Mucor hiemalis strain (SMU-21) against adults of Bactrocera oleae and Ceratitis capitata (Diptera: Tephritidae). J Econ Entomol. 2006;99(5):1657-64.

46. Chaurasia A, Lone Y, Wani O, Gupta US. Effect of certain entomopathogenic fungi on oxidative stress and mortality of Periplaneta americana. Pestic Biochem Physiol. 2016;127:28-37.

47. Aslanturk A, Kalender S, Uzunhisarcikli M, Kalender Y. Effects of methidathion on antioxidant enzyme activities and malondialdehyde level in midgut tissues of Lymantria dispar (Lepidoptera) larvae. J Entomol Res Soc. 2011;13(3):27-38.

48. Barata C, Lekumberri I, Vila-Escalé M, Prat N, Porte C. Trace metal concentration, antioxidant enzyme activities and susceptibility to oxidative stress in the tricoptera larvae Hydropsyche exocellata from the Llobregat river basin (NE Spain). Aquat Toxicol. 2005;74(1):3-19.

49. Sezer B, Ozalp P. Effect of juvenile hormone analogue, pyriproxyfen on antioxidant enzymes of greater wax moth, Galleria mellonella (Lepidoptera: Pyralidae: Galleriinae) larvae. Pak J Zool. 2015;47(3):665-9.

50. Karthi S, Sankari R, Shivakumar MS. Ultraviolet-B light induced oxidative stress: effects on antioxidant response of Spodoptera litura. J Photoch Photobiol B: Biology. 2014;135:1-6.

51. Ali A, Rashid MA, Huang QY, Lei CL. Influence of UV-A radiation on oxidative stress and antioxidant enzymes in Mythimna separata (Lepidoptera: Noctuidae). Environ Sci Pollut Res. 2017;24(9):8392-8.
52. Li X, Luo L, Karthi S, Zhang K, Luo J, Hu Q, Weng Q. Effects of 200 Gy 60Co$\gamma$ radiation on the regulation of antioxidant enzymes, Hsp70 genes, and serum molecules of Plutella xylostella (Linnaeus). Molecules. 2018;23(5):1011.

53. Zhang Y, Wang Z, Huang D. Interrelation between carboxylesterase and glutathione-S-transferase in Apriona germari larvae and secondary metabolites of poplar trees. Sci Silvae Sin. 2001;37(3):106-11.

54. Sanchez-Gomez FJ, Diez-Dacal B, García-Martín E, Agundez JA, Pajares MA, Perez-Sala D. Detoxifying enzymes at the cross-roads of inflammation, oxidative stress, and drug hypersensitivity: role of glutathione transferase P1-1 and aldose reductase. Front Pharmacol. 2016:7:237-47.

55. Ding Z. Studies on Differential susceptibility and its mechanisms of different population of Ditylenchus destructor to acetylcholinesterase inhibitor. Hunan: Doctoral dissertation, Ph. D. dissertation. Hunan Agricultural University; 2007.

56. Gholamzadeh-Chitgar M, Hajizadeh J, Ghadamyari M, Karimi-Malati A, Hoda $\mathrm{H}$. Effect of sublethal concentration of Beauveria bassiana fungus on demographic and some biochemical parameters of predatory bug, Andrallus spinidens Fabricius (Hemiptera: Pentatomidae) in laboratory conditions. TJS. 2017;15(2):160-7.

57. Jia M, Cao G, Li Y, Tu X, Wang G, Nong X, Zhang Z. Biochemical basis of synergism between pathogenic fungus Metarhizium anisopliae and insecticide chlorantraniliprole in Locusta migratoria (Meyen). Sci Rep. 2016;6:28424-34.

58. Hoffmann JA. Innate immunity of insects. Curr Opin Immunol. 1995;7(1):4-10.

59. Hoffmann JA. The immune response of Drosophila. Nature. 2003;426(6962):33.

60. da Silva C, Dunphy GB, Rau ME. Interaction of hemocytes and prophenoloxidase system of fifth instar nymphs of Acheta domesticus with bacteria. Dev Comp Immunol. 2000;24(4):367-79.

61. Gillespie JP, Burnett C, Charnley AK The immune response of the desert locust Schistocerca gregaria during mycosis of the entomopathogenic fungus, Metarhizium anisopliae var acridum. J Insect Physiol. 2000:46(4):429-37.

62. Giglio A, Battistella S, Talarico FF, Brandmayr TZ, Giulianini PG. Circulating hemocytes from larvae and adults of Carabus (Chaetocarabus) lefebvrei Dejean 1826 (Coleoptera, Carabidae): cell types and their role in phagocytosis after in vivo artificial non-self-challenge. Micron. 2008;39(5):552-8.

63. Giulianini PG, Bertolo F, Battistella S, Amirante GA. Ultrastructure of the hemocytes of Cetonischema aeruginosa larvae (Coleoptera, Scarabaeidae): involvement of both granulocytes and oenocytoids in in vivo phagocytosis. Tissue Cell. 2003:35(4):243-51.

64. Costa SC, Ribeiro C, Girard PA, Zumbihl R, Brehélin M. Modes of phagocytosis of gram-positive and gram-negative bacteria by Spodoptera littoralis granular haemocytes. J Insect Physiol. 2005;51(1):39-46.

65. Begum R, Gohain R. Detoxication of PP'DDT by the hemocytes of the fifth instar Philosamia ricini Boisd. J Environ Biol. 1996;17(2):149-55.

66. Gayfullina LR, Saltykova ES, Nikolenko AG. Cellular immune reactions participating in resistance formation of Colorado beetle (Leptinotarsa decemlineata say) larvae and imago to a biopreparation for potato. Resistant Pest Manage Newsl. 2006;15:22-4.

67. Fan JQ, Chen XR, Hu QB. Effects of destruxin a on hemocytes morphology of Bombyx mori. J Integr Agric. 2013;12(6):1042-8.

68. Silva JE, Boleli IC, Simões ZL. Hemocyte types and total and differential counts in unparasitized and parasitized Anastrepha obliqua (Diptera, Tephritidae) larvae. Braz J Biol. 2002;62(4A):689-99.

69. Falleiros ÂM, Bombonato MT, Gregório EA. Ultrastructural and quantitative studies of hemocytes in the sugarcane borer, Diatraea saccharalis (Lepidoptera: Pyralidae). Braz Arch Biol Technol. 2003:46(2):287-94.

70. Baggio MV, Ferreira MD, Monteiro AC, Maldonado Junior W, Lemos MV. Pathogenicity of Aspergillus westerdijkiae to females and oothecae of Periplaneta Americana. Ciência Rural. 2016;46(1):20-5.

71. Bawin T, Seye F, Boukraa S, Zimmer JY, Raharimalala FN, Ndiaye M, Compere $P$, Delvigne F, Francis F. Histopathological effects of Aspergillus clavatus (Ascomycota: Trichocomaceae) on larvae of the southern house mosquito, Culex quinquefasciatus (Diptera: Culicidae). Fungal Biol. 2016;120(4):489-99.

72. Bawin T, Seye F, Boukraa S, Zimmer JY, Raharimalala FN, Zune Q, Ndiaye M, Delvigne F, Francis F. Production of two entomopathogenic Aspergillus species and insecticidal activity against the mosquito Culex quinquefasciatus compared to Metarhizium anisopliae. Biocontrol Sci Tech. 2016;26(5):617-29.

73. Duan Y, Wu H, Ma Z, Yang L, Ma D. Scanning electron microscopy and histopathological observations of Beauveria bassiana infection of Colorado potato beetle larvae. Microb Pathog. 2017;111:435-9.

74. Ferrarese $R$, Brivio M, Congiu T, Falabella P, Grimaldi A, Mastore M, Perletti G Pennacchio F, Sciacca L, Tettamanti G, Valvassori R. Early suppression of immune response in Heliothis virescens larvae by the endophagous parasitoid Toxoneuron nigriceps. Invertebr Surviv J. 2005;2(1):60-8. 
75. Habeeb SM, El-Hag HA. Ultrastructural changes in hemocyte cells of hard tick (Hyalomma dromedarii: Ixodidae): a model of Bacillus thuringiensis var. thuringiensis H14;-endotoxin mode of action. Am-Euras J Agric Environ Sci. 2008; $3: 829-36$

76. Kaur HP, Singh B, Thakur A, Kaur A, Kaur S. Studies on immunomodulatory effect of endophytic fungus Alternaria alternata on Spodoptera litura. J AsiaPacific Entomol. 2015;18(1):67-75.

77. Thakur A, Singh V, Kaur A, Kaur S. Suppression of cellular immune response in Spodoptera litura (Lepidoptera: Noctuidae) larvae by endophytic fungi Nigrospora oryzae and Cladosporium uredinicola. Ann Entomol Soc Am. 2014; 107(3):674-9.

78. Kaur M, Chadha P, Kaur S, Kaur A, Kaur R, Yadav AK, Kaur R. Evaluation of genotoxic and cytotoxic effects of ethyl acetate extract of Aspergillus flavus on Spodoptera litura. J Appl Microbiol. 2019;126(3):881-93.

79. Singh B, Thakur A, Kaur S, Chadha BS, Kaur A. Acetylcholinesterase inhibitory potential and insecticidal activity of an endophytic Alternaria sp. from Ricinus communis. Appl Biochem Biotechnol. 2012;168(5):991-1002.

80. Kaur M, Chadha P, Kaur S, Kaur A, Kaur R, Yadav AK, Kaur R. Schizophyllum commune induced genotoxic and cytotoxic effects in Spodoptera litura. Sci Rep. 2018;8(1):1-2

81. Sharma M, Chadha BS, Kaur M, Ghatora SK, Saini HS. Molecular characterization of multiple xylanase producing thermophilic/ thermotolerant fungi isolated from composting materials. Lett Appl Microbiol. 2008:46(5):526-35.

82. Aebi H. Catalase in vitro. Methods Enzymol. 1984;105:121-6.

83. Asada K. Chloroplasts: formation of active oxygen and its scavenging. Methods Enzymol. 1984;105:422-9.

84. Kono Y. Generation of superoxide radical during autoxidation of hydroxylamine and an assay for superoxide dismutase. Arch Insect Biochem Biophy. 1978;186(1):189-95.

85. Habig WH, Pabst MJ, Jakoby WB. Glutathione S-transferases the first enzymatic step in mercapturic acid formation. J Biol Chem. 1974;249(22): 7130-9.

86. Wang Y, Hu M, Chiang MW, Shin PK, Cheung SG. Characterization of subpopulations and immune-related parameters of hemocytes in the green-lipped mussel Perna viridis. Fish Shellfish Immun. 2012;32(3):381-90.

\section{Publisher's Note}

Springer Nature remains neutral with regard to jurisdictional claims in published maps and institutional affiliations.

Ready to submit your research? Choose BMC and benefit from:

- fast, convenient online submission

- thorough peer review by experienced researchers in your field

- rapid publication on acceptance

- support for research data, including large and complex data types

- gold Open Access which fosters wider collaboration and increased citations

- maximum visibility for your research: over $100 \mathrm{M}$ website views per year

At $\mathrm{BMC}$, research is always in progress.

Learn more biomedcentral.com/submissions 